\title{
Expression of the human melanocortin-4 receptor gene is controlled by several members of the Sp transcription factor family
}

\author{
A Blondet, J Gout, P Durand, M Bégeot and D Naville \\ Inserm U418-Inra UMR 1245 and IFR 62, Hôpital Debrousse and Claude Bernard University, Lyon, France \\ (Requests for offprints should be addressed to D Naville; Email:naville@lyon.inserm.fr)
}

\begin{abstract}
The melanocortin-4 receptor (MC4-R) plays a key role in the hypothalamic control of food intake, lending importance to the understanding of the mechanisms that regulate its expression. To identify factors controlling the expression of the human (h) MC4- $R$ gene, a fragment containing $1253 \mathrm{bp}$ of the $5^{\prime}$-flanking region of the $h M C 4-R$ gene was isolated. A series of hMC4-R luciferase constructs were developed and used to transiently transfect HEK293 and GT1-7 cell lines, both expressing endogenous MC4-R mRNA. Deletion analysis of the $1253 \mathrm{bp}$ fragment showed that the basal promoter activity is mainly restricted to the $179 \mathrm{bp}$ upstream of the transcription start site in both cell types. Mutation of a putative Sp1-binding site located at position $-76 \mathrm{bp}$ resulted in a dramatic reduction of the luciferase activity in HEK293 and GT1-7 cells by 87 and $80 \%$ respectively. Both in vitro and in vivo studies (gel shift and chromatin immunoprecipitation analyses) revealed binding of both Sp1 and Sp3 to this site in HEK293 cells. Cotransfection with an Sp1 expression vector in Drosophila cells that do not express Sp1, in conjunction with treatment of HEK293 cells with mithramycin A, a specific inhibitor of Sp1, confirmed the role of Sp1. For the first time, we have demonstrated that the constitutive activity of the hMC4-R promoter is dependent upon Sp transcription factors.
\end{abstract}

Journal of Molecular Endocrinology (2005) 34, 317-329

\section{Introduction}

The melanocortins (adrenocorticotrophic hormone, and $\alpha$-, $\beta$ - and $\gamma$-melanocyte stimulating hormone $(\mathrm{MSH}))$ (Gee et al. 1983) are derived from the precursor protein pro-opiomelanocortin (POMC). The POMC gene is expressed in the hypothalamic arcuate nucleus and in the nucleus of the solitary tract (Jacobowitz \& O'Donohue 1978, Joseph et al. 1983, Palkovits et al. 1987). These hormones mediate their effects through G-protein coupled receptors by stimulating adenylate cyclase (Mountjoy et al. 1992). To date, five melanocortin receptor subtypes with different patterns of expression in brain and peripheral tissues have been cloned and characterized (Chhajlani \& Wikberg 1992, Chhajlani et al. 1993, Gantz et al. 1993a,b, Mountjoy et al. 1992). Melanocortins are known to have a broad spectrum of physiological actions including regulation of melanocyte pigmentation (De Wied \& Jolles 1982), thermoregulation (Feng et al. 1987), regulation of obesity (Fan et al. 1997), control of the cardiovascular system (Li et al. 1996) and learning and memory (De Wied \& Croiset 1991) as well as immunomodulatory effects.

Activation of melanocortin-4 receptor (MC4-R) by $\alpha$-MSH increases energy expenditure and decreases food intake. Studies involving targeted gene deletion in mice demonstrate that loss of $M C 4-R$ results in obesity, hyperphagia and hyperinsulinaemia (Huszar et al. 1997, Marsh et al. 1999). In addition, treatment of the paraventricular nucleus or the fourth ventricle with an MC4-R receptor agonist (MTII) suppresses food intake (Giraudo et al. 1998). At the central level, an opioid-induced reduction of ${ }^{125}$ I-labelled NDP- $\alpha$-MSH binding in the ventrolateral striatum has been reported (Alvaro et al. 1996), as well as food restrictioninduced binding of ${ }^{125} \mathrm{I}$-labelled $\mathrm{Nle}^{4}$, D-Phe ${ }^{7}(\mathrm{NDP})-\alpha$ MSH in several hypothalamic nuclei (Harrold et al. 1999) of the rat.

MC4-R +/-mice display an intermediary obese phenotype between that of wild-type mice and MC4-R $-/-$ mice, indicating that the presence of only one mutated allele is associated with obesity (Huszar et al. 1997). In the human, an inactivating mutation present in only one allele of the human (h) $h M C 4-R$ gene-coding sequence induces a morbid obesity (Vaisse et al. 1998, Yeo et al. 1998). Because 50\% expression of the normal $h M C 4-R$ gene is not sufficient to obtain a normal phenotype, the constitutive expression of the $M C 4-R$ gene must be strongly controlled, although there are few data available regarding this regulation (Alvaro et al. 1996, Harrold et al. 1999).

The mouse MC4-R (mMC4-R) and hMC4-R gene promoters have been cloned but the factors involved in their basal expression are unknown (Dumont et al. 2001, 
Lubrano-Berthelier et al. 2003). Herein, we have demonstrated that the maximal basal promoter activity is retained by the proximal $179 \mathrm{bp}$ of the promoter and one Spl-binding site is absolutely required for the transcriptional activation of the $h M C 4-R$ gene.

\section{Materials and methods}

\section{Materials}

Penicillin, streptomycin, fetal calf serum (FCS), Dulbecco's Modified Eagle's Medium/Ham's nutrient mixture (DMEM/F-12, $15 \mathrm{mM}$ Hepes), Dulbecco's Eagle Medium, Schneider insect medium and restriction enzymes were purchased from Invitrogen. Oligonucleotides were prepared by Sigma-Genosys (Cambridge, UK). Mithramycin A was purchased from Coger (Paris, France).

\section{Characterization of the $h M C 4-R$ CDNA $5^{\prime}$-end}

Total RNA $(3 \mu \mathrm{g})$ from human brain (Clontech) was analysed to obtain the complete cDNA sequence of the $h M C 4-R$ gene using rapid amplification of the $5^{\prime}-\mathrm{cDNA}$ end ( $5^{\prime}$-RACE). This analysis was performed using the GeneRacer kit (Invitrogen) according to the instructions provided. Human brain cDNA was amplified using the specific primer MC4-2 and the GeneRacer primer 1 (5'-cgactggagcacgaggacactga- $\left.3^{\prime}\right)$. The primary PCR product was used as template for a secondary PCR using the nested specific primer MC4 -3 (5'-ctcactggcattgctgtgc agtctgt- $\left.3^{\prime}\right)$ and the GeneRacer nested primer 2 $\left(5^{\prime}\right.$-ggacactgacatggactgaaggagta- $\left.3^{\prime}\right)$. The PCR products were cloned into pCR4-Topo using the TOPO TA cloning kit (Invitrogen). The different clones were obtained from two independent cDNA syntheses. DNA from individual colonies was sequenced using a T7 sequencing kit (Amersham Biosciences).

\section{Reporter-vector constructions}

Luciferase reporter plasmids containing $h M C 4-R$ gene promoter were constructed by cloning deleted fragments of the 5'-flanking sequence of the MC4- $R$ gene into pGL3 basic. For the longer constructs, PGR reactions were performed using Taq Extra Polymerase II (Eurobio, Les Ulis, France) a sense primer containing an NheI restriction endonuclease site at the $5^{\prime}$-end, and an antisense primer complementary to exon 1 ( $5^{\prime}$-gacc agatctccagcctgagcgttgct- $3^{\prime}$ ) containing a BglII site and human genomic DNA as a template. The resulting fragments were subcloned into the NheI-BgIII digested pGL3 basic vector. The sequence was confirmed to ensure that there were no PGR-generated mutations. Vector $\mathrm{p}(-279 /+26)$ luc was digested with PvuII enzyme to generate the $\mathrm{p}(-20 /+26)$ luc vector.
Construction of vectors containing mutated fragments were obtained using the Quick Change site-directed mutagenesis kit from Stratagene (Ozyme, Montigny-leBretonneux, France). The presence of the desired mutation inside the site was confirmed by sequencing.

\section{Cell culture and transfection}

The mouse hypothalamic GT1-7 and human embryonic kidney 293 (HEK293) cells were used to study the promoter activity of the different constructs. The day before transfection, cells were plated in six-well dishes at 200000 cells per well in DMEM/F-12 supplemented with $7 \cdot 5 \%$ FCS, penicillin $(100 \mathrm{U} / \mathrm{ml})$, streptomycin $(0 \cdot 1 \mathrm{mg} / \mathrm{ml})$, glutamine $(100 \mathrm{U} / \mathrm{ml})$ for HEK293 cells and in Dulbecco's Eagle Medium supplemented with $10 \%$ FCS, penicillin $(100 \mathrm{U} / \mathrm{ml})$, streptomycin $(0 \cdot 1 \mathrm{mg} /$ $\mathrm{ml})$ and glutamine $(100 \mathrm{U} / \mathrm{ml})$ for GT1-7 cells.

Transient transfections were performed in serum-free medium without antibiotics using the LipofectAmine Plus reagent (Invitrogen) in the presence of $1 \mu \mathrm{g}$ of the $h M C 4-R$ gene construct and $1 \mu \mathrm{g} \mathrm{pRV}-\beta \mathrm{Gal}$ per well. Cells were incubated with DNA-LipofectAmine Plus complexes for $3 \mathrm{~h}$ at $37^{\circ} \mathrm{C}$ under $5 \% \mathrm{CO}_{2}$. After $3 \mathrm{~h}$ the serum-free medium was replaced with complete medium. The luciferase and $\beta$-Gal activities were measured 3 days after transfection using the appropriate substrates (Promega). Because the transfection efficiency was constant, $\mathrm{pRV}-\beta \mathrm{Gal}$ was not used systematically in all experiments.

In some experiments, the cells were serum starved $24 \mathrm{~h}$ prior to transfection, and mithramycin A was added to a final concentration of $100 \mathrm{nM}$. Cells were harvested and analysed for luciferase activity $24 \mathrm{~h}$ after transfection.

Schneider Line 2 cells (SL-2) were maintained at $25{ }^{\circ} \mathrm{C}$ in Schneider medium supplemented with $10 \%$ FCS and antibiotics. SL-2 cells were transfected by the calcium phosphate method (Graham \& van der Eb 1973). Briefly, cells were seeded in six-well dishes at 300000 cells per well $24 \mathrm{~h}$ before transfection. Each well received $1 \mu \mathrm{g}$ promoter-reporter gene construct and various amounts of expression plasmids for $\mathrm{Spl}$ as indicated in Results (pPacSpl; a gift from $\mathrm{R}$ Tjian, University of California, Berkeley, CA, USA). Luciferase activity, normalized to the protein concentration of the extract, was measured. Protein concentrations were determined with the BCA protein assay system (Pierce Chemical Co., Montluçon, France).

\section{Electrophoretic mobility shift assay (EMSA)}

Nuclear extracts from GT1-7 and HEK293 cells were prepared as previously described (Schreiber et al. 1989). Synthetic oligonucleotide probes (Table 1) were prepared by $5^{\prime}$-end labelling of double-stranded 
Table 1 Sequences of the double-stranded oligonucleotides used for the EMSA experiments and for site-directed mutagenesis studies (the sense strand only is shown). Mutations sites are in bold

\section{Sp-C/EBP $\beta-M C 4-R$ $\mathrm{C} / \mathrm{EBP} \beta$ mut \\ Consensus C/EBP $\beta$ \\ Sp1-MC4-R \\ Mut Sp1-MC4-R \\ Consensus Sp1}

\begin{abstract}
$5^{\prime}$-gtctcacagactccattgcattgg-3'
$5^{\prime}$-gtctcacagaattacattgcattgg-3'

5' -ctagggcttgcgcaatctatattcg-3'

5'-ggaagcagaggaggagccaccgtg-3'

$5^{\prime}$-ggaagcagacatagagccaccgtg-3'

$5^{\prime}$-attcgatcggggcggggcgagc- $3^{\prime}$
\end{abstract}

oligonucleotides using $\left[\gamma_{-}{ }^{32} \mathrm{P}\right] \mathrm{ATP}$ and $\mathrm{T} 4$ polynucleotide kinase (Invitrogen). For EMSA, nuclear extracts $(10 \mu \mathrm{g})$ were incubated at $4{ }^{\circ} \mathrm{C}$ for $15 \mathrm{~min}$ in a binding reaction that contained $10 \mathrm{mM}$ Hepes $(\mathrm{pH} 8), 50 \mathrm{mM}$ $\mathrm{KCl}, \quad 0.1 \mathrm{mM}$ EDTA, $2 \mathrm{mM}$ dithiothreitol, $5 \mathrm{mM}$ $\mathrm{MgCl}_{2}, 50 \mathrm{mM} \mathrm{NaCl}, 4 \mathrm{mM}$ spermine, $8 \%$ Ficoll and $1 \mu \mathrm{g}$ poly dIdC-poly dIdC (Amersham), with or without $\mathrm{ZnCl}_{2}(0.1 \mathrm{mM})$. For the competition assays, a 200-fold molar excess of unlabelled double-stranded oligonucleotide used as competitor was added to the reaction mixture. The radiolabelled DNA probe (10 000 c.p.m.) was then added and the incubation continued for $15 \mathrm{~min}$ at $4{ }^{\circ} \mathrm{C}$. Samples were electrophoresed on a $5 \%$ non-denaturing polyacrylamide gel in $0.5 \times$ Trisborate-EDTA at $15^{\circ} \mathrm{C}$. The gels were dried under vacuum and analysed by autoradiography.

In some experiments, nuclear extracts were preincubated (overnight at $4{ }^{\circ} \mathrm{C}$ ) in the presence of polyclonal antibodies against either the human Spl (Active Motif Europe, Rixensart, Belgium) or the human Sp3 (Santa Cruz, Tebu, Le Perray-en-Yvelines, France) before adding the labelled probe.

\section{Western blotting}

Thirty micrograms of nuclear extracts prepared from HEK 293 or GT1-7 cells were separated by SDS-10\% polyacrylamide gel electrophoresis and transferred to nitrocellulose membrane. Immunoblotting was performed using anti-Spl antibodies (Santa Cruz) and the Envision System Labelled-Polymer-HRP antiRabbit (DakoCytomation, Trappes, France). Blots were revealed using the ECL Plus Western Blotting Detection System (Amersham).

\section{Chromatin immunoprecipitation assay (ChIP)}

In vivo molecular interaction between $\mathrm{Sp} 1$ (or Sp3) and the $h M C 4-R$ gene promoter was investigated using the ChIP-IT kit (Active Motif). Briefly, cells were fixed with $1 \%$ formaldehyde at room temperature for $10 \mathrm{~min}$. After washing with cold PBS, the cross-linking was stopped by addition of a glycine-containing buffer and incubation at room temperature for $5 \mathrm{~min}$. Cells were then scraped and lysed in a buffer containing phenylmethylsulphonyl fluoride and a protease inhibitor cocktail (Complete; Roche). The lysate was sonicated $15 \times 20 \mathrm{~s}$ to shear the DNA to a length between 200 and $1000 \mathrm{bp}$. After pre-clearing in the presence of salmon sperm DNA/Protein G agarose beads, the sheared chromatin was incubated with polyclonal antibodies against Sp1 (Active Motif), Sp3 (Santa Cruz) or non-immune $\mathrm{IgG}$, at $4{ }^{\circ} \mathrm{C}$ overnight on a rotator. Before incubation an aliquot of DNA (corresponding to the input DNA) was removed. The DNA/Sp/Sp antibody complex was recovered by addition of salmon sperm DNA/Protein $\mathrm{G}$ agarose beads and incubation for $1.5 \mathrm{~h}$ at $4{ }^{\circ} \mathrm{C}$ on a rotator. After extensive washes of the beads, the DNA was eluted from the Protein G. The cross-link was then reversed and RNA removed after incubation in the presence of $\mathrm{NaCl}$ and RNase $\mathrm{A}$ at $65^{\circ} \mathrm{C}$ for at least $4 \mathrm{~h}$ (the input DNA was also subjected to this treatment and the following). Proteins were then digested in the presence of EDTA and proteinase $\mathrm{K}$ before the DNA purification.

For PGR, $5 \mu \mathrm{l}$ of immunoprecipitated DNA or one-to-ten diluted input DNA were used. Four sets of PCR primers were used: a first primer pair flanked and amplified the hMC4-R Spl-76 site and a second (negative control) primer pair amplified part of the hMC4-R-coding sequence. The third and fourth primer pairs amplified a sequence containing the mMC4-R Sp1-87-binding site and part of the mMC4-R-coding sequence (negative control) respectively.

\section{RT-PCR}

Semi-quantitative RT-PGR was used to study the expression of the endogenous $M C 4-R$ gene expression in HEK 293 and GT1-7 cells. Total RNA was extracted from the cells after a $24 \mathrm{~h}$ treatment with or without mithramycin A. To rule out the possibility that PCR products could result from the amplification of genomic DNA contaminating the RNA samples, RNA samples were treated by DNAse before the reverse transcription. First-strand cDNA was prepared with $1 \mu \mathrm{g}$ RNA using MMLV reverse transcriptase (Invitrogen). PCR reactions were performed in the presence of $2 \mu \mathrm{l}$ of reverse transcribed cDNA using EuroblueTaq (Eurobio). The number of cycles used to amplify hMC4-R or mMC4-R cDNA, cyclophilin and GAPDH cDNA (used for normalization in HEK293 and GT1-7 cells respectively) was first determined to ensure that the end of the reaction for the control samples was in the middle of the exponential curve of amplification.

\section{Data analysis}

Data are expressed as means \pm S.E.M. of at least three independent experiments performed in triplicate using 
two different preparations of vector to rule out plasmid preparation inequalities. Statistical analysis was performed using one-way ANOVA analysis followed by post hoc testing with Fisher's protected least square difference, except for mithramycin A experiments where the Student's $t$-test was used. Differences were considered significant when $P<0 \cdot 05$.

\section{Results}

\section{Characterization of the hMC4-R cDNA 5'-end and promoter}

Following RACE-PCR on mRNA encoding hMC4-R, a unique band of $600 \mathrm{bp}$ was obtained. After subcloning into pCR4-TOPO vector, 53 different clones were purified and sequenced. All cDNA fragments appeared to contain the same $5^{\prime}$-untranslated sequence of $427 \mathrm{bp}$ in size. This indicated the presence of one major transcription start site located $427 \mathrm{bp}$ upstream from the translation start codon ATG. Comparison between the hMC4-R genomic sequence (accession number Genbank NM_005912) and the cDNA fragment indicated that the $h \bar{M} C 4-R$ gene did not contain any intron in the sequenced hMC4-R 5'-flanking region. The DNA sequence upstream of the major transcription start site contains a CAAT box (located at - $100 \mathrm{bp}$ in antisense orientation) but lacks a typical TATA box (Fig. 1). The sequence also revealed the presence of several putative binding sites for known transcription factors, in particular three Spl-binding sites located at nucleotides $-76,-179$ and $-275 \mathrm{bp}$ from the transcription start site (Fig. 1).

\section{Functional analysis of the $5^{\prime}$-flanking region of the hMC4-R}

In order to characterize the regions involved in the regulation of the basal expression of the $h M C 4-R$ gene promoter, a fragment containing the sequence from -1253 to +26 was subcloned into the pGL3 basic luciferase reporter vector. A series of deletion constructs was generated and used to transiently transfect GT1-7 cells, expressing endogenous mMC4-R, and HEK293 cells, expressing endogenous hMC4-R mRNA (Dumont et al. 2001). The longest construct, $\mathrm{p}(-1253 /+26)$ luc, conferred a strong constitutive luciferase reporter gene expression with 100- and 30-fold increases compared with pGL3 basic in HEK293 and GT1-7 cells respectively (Fig. 2A and B). Truncation of the promoter up to the first $279 \mathrm{bp}$, induced a slight decrease $(10 \%$; $P<0 \cdot 05)$ of the basal expression in HEK293 cells (Fig. 2A) but this effect is more pronounced in GT1-7 cells (Fig. 2B). No significant decrease was observed upon deletion up to $-179 \mathrm{bp}$. However, subsequent deletions up to $-98 \mathrm{bp}$ reduced $(P<0 \cdot 05)$ the luciferase activity in

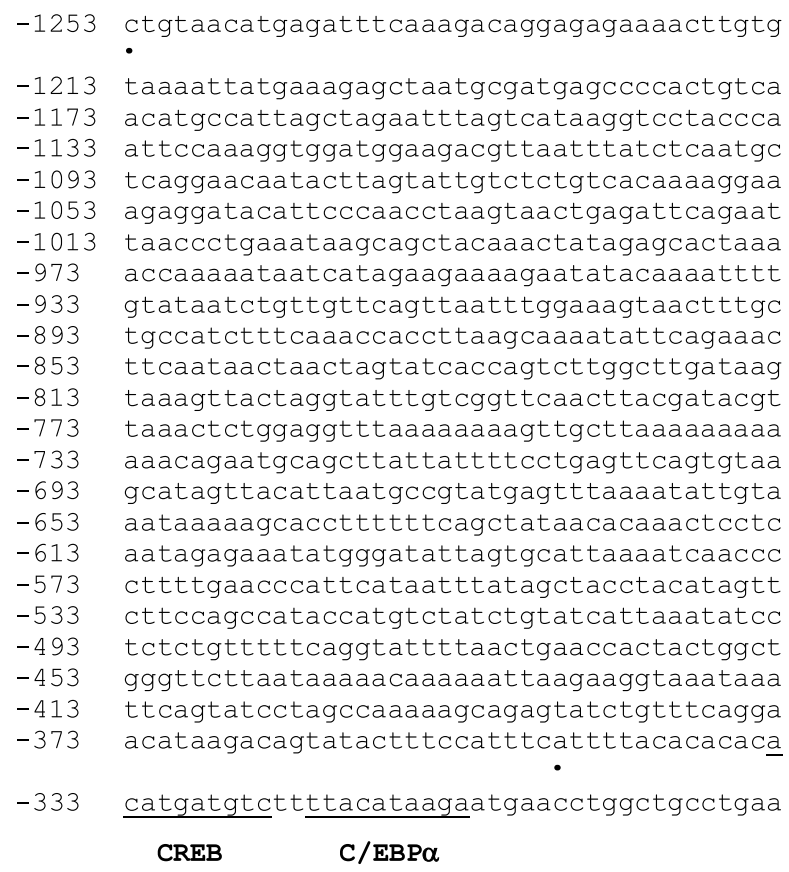

-293 gatagcttgtttgatatcacagaatggcctctagggatc Sp1

-253 aagttgtttccctgaaaacttaaaagggaaattcagtc

-213 tcttatccggcttgcttctcgacttcagacttcaggagct - Sp1

-173 tctgcatctgaatctgtgtcaccctgcaatttgtgtctct AP1

GATA-1

$-133$ gaaacataatcctgtctcacagactcccattgcattggga $\mathrm{C} / \mathrm{EBP} \beta$

Oct1

-93 ttggtcagaaggaagcagaggaggagccaccgtgaacatg GATA-1 Sp1

ttttttctctccacacatcataaaatcagcagctggc

oct1

-13 gcctacagcccctAACACTCAAAGCAACGCTCAGGCTGG

Figure 1 Nucleotide sequence of the $5^{\prime}$-flanking region of the $h M C 4-R$ gene. Nucleotide numbering starts with

+1 corresponding to the major transcription start site defined by 5 '-RACE. Potential binding sites for transcription factors predicted by the software (AliBaba 2.1) inside the sequence -347 to +1 are underlined. The CAAT box is in bold. The first nucleotide of each construct is shown (.). The GenBank accession number for the nucleotide sequence is AY268932. 
(A)

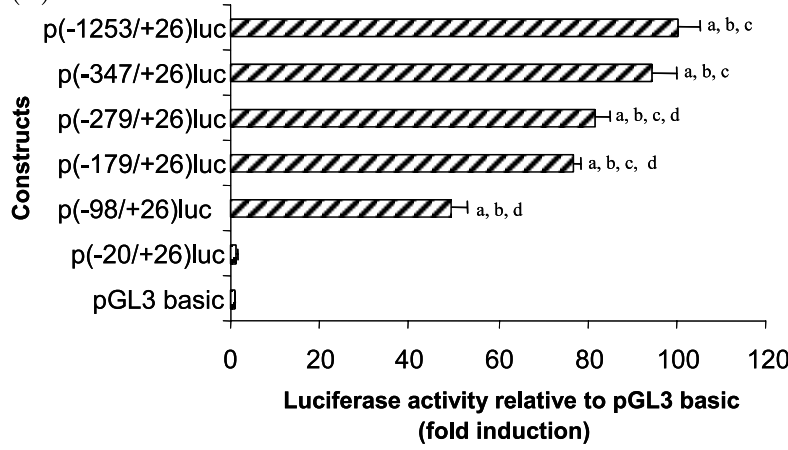

(B)

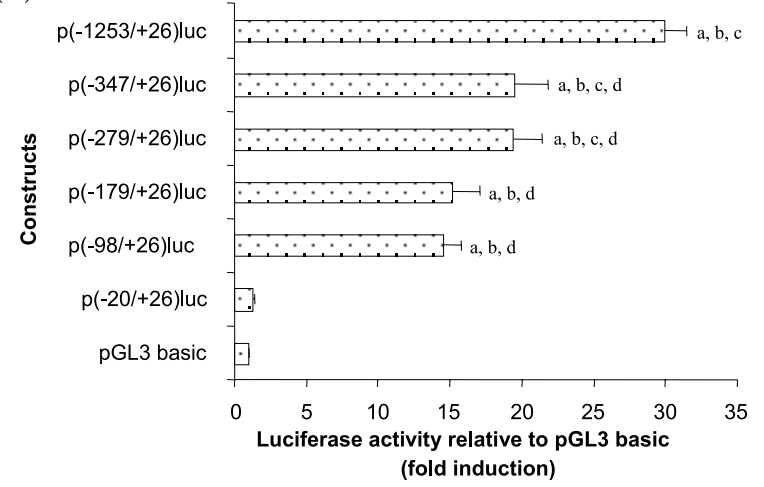

Figure 2 Functional analysis of the $h M C 4-R$ gene promoter. Analysis of the luciferase activity relative to pGL3 basic was performed after transient transfection of HEK293 (A) and GT1-7 (B) cell lines, using constructs containing deleted fragments of the $h M C 4-R$ gene promoter. Values represent means \pm S.E.M. of three different experiments performed in triplicate. ' $a$ ' indicates values significantly different from those obtained with the promoterless vector pGL3 basic $(P<0.0001)$; ' $b$ ' indicates values significantly different from $\mathrm{p}(-20 /+26)$ luc vector $(P<0.001)$; ' $C$ ' indicates values significantly different from $p(-98 /+26)$ luc vector $(P<0.01)$; ' $d$ ' indicates values significantly different from $p(-1253 /+26)$ luc vector $(P<0.001)$.

HEK 293 cells by $35 \%$, which indicated that the region containing the sequence between -179 and $-98 \mathrm{bp}$ is partly involved in the basal promoter activity in these cells but not in GT1-7 cells. Deletions up to $-20 \mathrm{bp}$ induced a very strong decrease (about 90\%) of the remaining luciferase activity in both cell types. These results clearly indicated that a second region, between -98 and $-20 \mathrm{bp}$, contains element(s) essential for the expression of $h M C 4-R$ gene promoter.

\section{Analysis of the region containing the sequence between -179 and -98 bp by mutagenesis and EMSA studies}

In this region, a GC-rich sequence extending from -100 to $-109 \mathrm{bp}$ is present corresponding to a putative binding site for Sp-like transcription factors but it is also
(A)

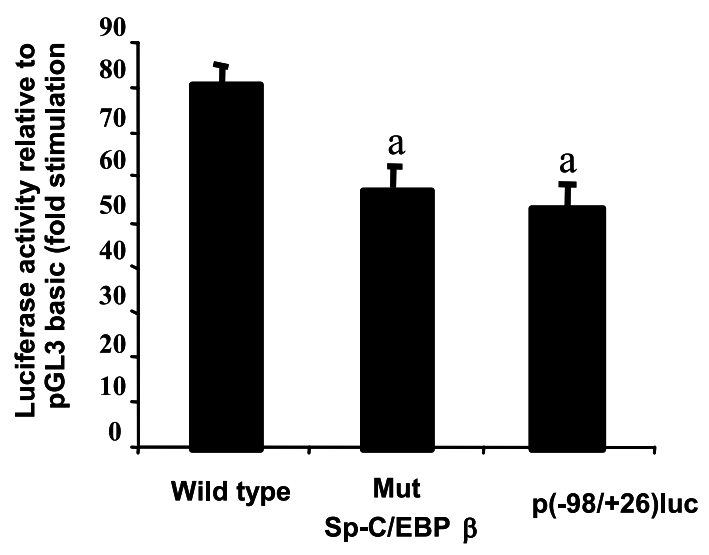

(B)

\section{Competitors : \\ Sp-C/EBP $\beta-M C 4-R$ Consensus C/EBP $\beta$}
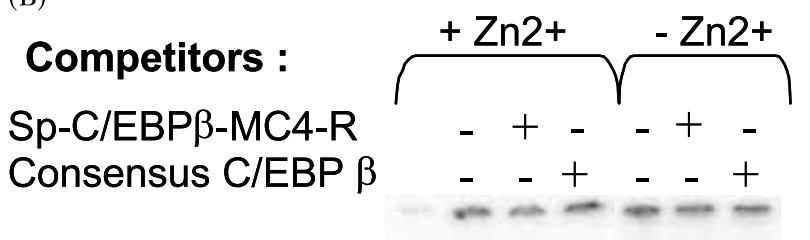

Figure 3 Analysis of the region located between -179 and $-98 \mathrm{bp}$ of the $h M C 4-R$ gene promoter: (A) Effects of a mutation in the putative Sp-C/EBP $\beta$-binding site on the constitutive $h M C 4-R$ gene promoter activity. The luciferase activity is expressed as the fold increase over the results obtained with pGL3 basic in transiently transfected HEK293 cells. Values represent the means \pm S.E.M. of three different experiments performed in triplicate. 'a' indicates values significantly different from wild-type $\mathrm{p}(-279 /+26)$ luc vector $(P<0 \cdot 05)$. (B): EMSA using oligonucleotide containing the Sp-C/EBP $\beta-h M C 4-R-$ binding site as a probe: The Sp-C/EBP $\beta$-hMC4-R oligonucleotide was 5 -end labelled and incubated with nuclear extracts obtained from HEK293 cells, either alone or in the presence of a 200 -fold molar excess of unlabelled double-stranded oligonucleotides (Sp-C/EBP $\beta$-MC4-R and consensus C/EBP $\beta$ ). EMSA experiments were performed with or without $\mathrm{Zn}^{2+}$. $\mathrm{U}=$ unbound probe. 
listed as a putative $\mathrm{C} / \mathrm{EBP} \beta$-binding site in the software AliBaba 2.1 (www.gene-regulation.com). Site-directed mutagenesis (Table 1) was used to alter this site in the context of the $\mathrm{p}(-279 /+26)$ luc construct. Results of

(A)

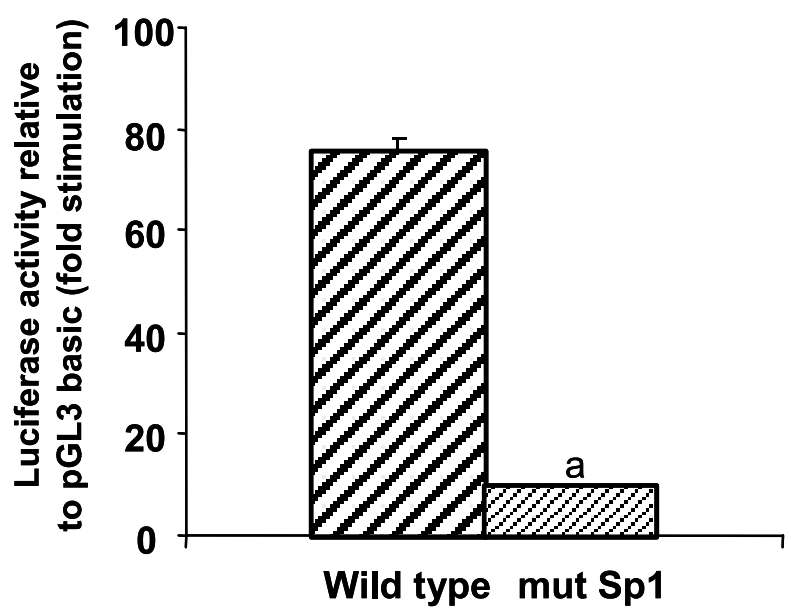

(B)

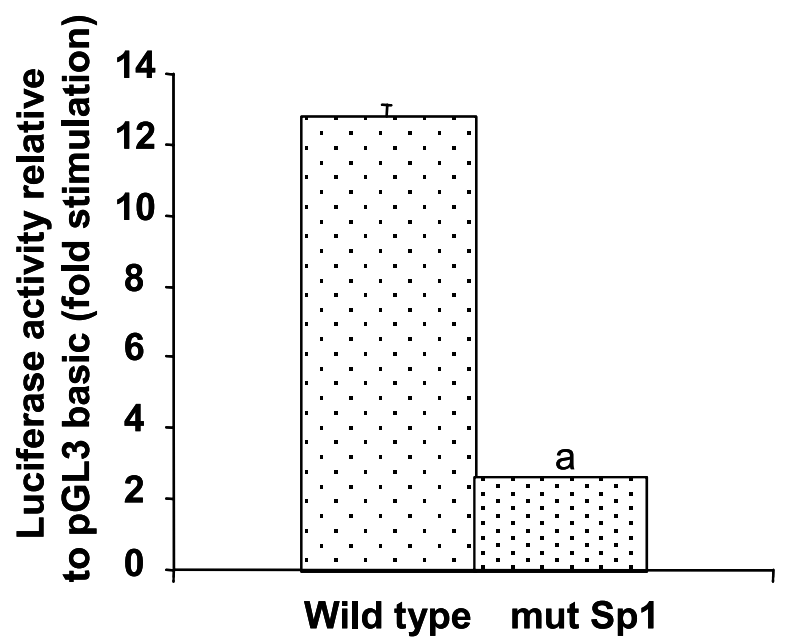

(C)

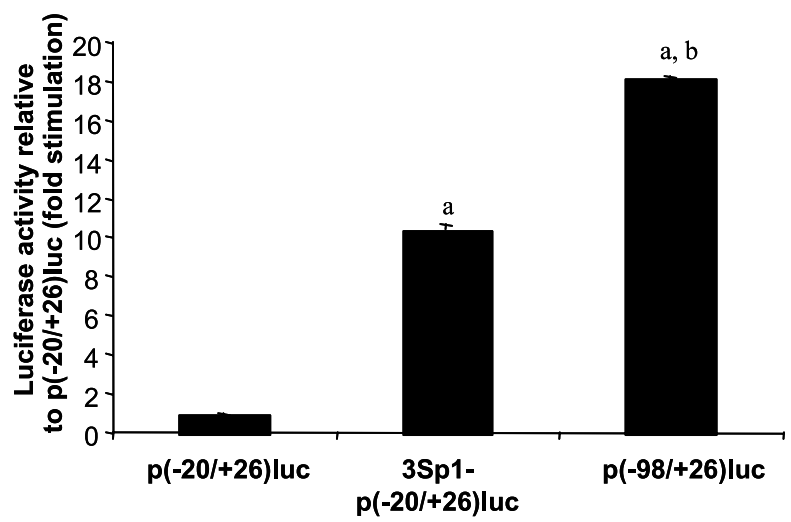

transient transfections, performed using HEK293 cells, are shown in Fig. 3A. A significant decrease of the luciferase activity was obtained as compared with the wild-type vector $(20 \%)$, but no significant difference was observed using the mutant construct compared with the $p(-98 /+26)$ luc construct (Fig. 3A). Mutation of this site had no effect when transfections were performed in GT1-7 cells (data not shown), as expected, since deletion of the sequence located between -179 and -98 bp did not modify the luciferase activity (Fig. 2B).

When EMSA experiments were performed using an oligonucleotide containing this putative Sp-C/EBP $\beta$ binding site in the presence of nuclear extracts prepared from HEK293 cells, a major complex (C1) was present in the absence of $\mathrm{Zn}^{2+}$ (Fig. 3B) and formation of this complex was inhibited by the presence of $\mathrm{Zn}^{2+}$. This complex was competed by a 200 -fold molar excess of unlabeled probe but not by a 200-fold excess of an oligonucleotide containing a $\mathrm{C} / \mathrm{EBP} \beta$ consensus sequence. All these results indicate that this element is not a binding site for $\mathrm{C} / \mathrm{EBP} \beta$ transcription factor. Moreover, the complex $\mathrm{C} 1$ did not contain a zinc-finger domain protein and thus the binding protein did not belong to the Sp transcription factor family.

\section{Analysis of the region containing the sequence $-98 /-20$ bp by mutagenesis and EMSA studies}

Sequence analysis revealed the presence of one Spl-binding motif in this region, located at position $-76 \mathrm{bp}$. Site-directed mutagenesis (Table 1) altering this Spl-binding site in the context of the $\mathrm{p}(-279 /+26)$ luc vector resulted in a very strong inhibition of the promoter activity in HEK293 cells (87\%) as well as in GT1-7 cells $(80 \%)$ compared with the wild-type construct (Fig. 4A and B). These results indicated that an intact Sp1-76-binding site is required for the basal promoter activity of the $h M C 4-R$ gene and confirmed above results showing that the region located between

Figure 4 Analysis of the region located between -98 and -20 bp of the $h M C 4-R$ gene promoter by mutagenesis. (A and B) Effects of a mutation inside the putative Sp1-binding site on the constitutive $h M C 4-R$ gene promoter activity. The luciferase activity is expressed as fold increase over the result obtained with pGL3 basic in transiently transfected HEK293 (A) and GT1-7 (B) cells. Values represent means \pm S.E.M. of three different experiments performed in triplicate. 'a' indicates values significantly different from wild-type $\mathrm{p}(-279 /+26)$ luc vector $(P<0.05)$. (C) Effect of the insertion of three Sp1-binding sites upstream of the $p(-20 /+26)$ luc vector. The luciferase activity is expressed as fold increase over the result obtained with pGL3 basic in transiently transfected HEK293 cell lines. Values represent means \pm S.E.M. of three different experiments performed in triplicate. 'a' indicates values significantly different from $\mathrm{p}(-20 /+26)$ luc vector $(P<0.001)$; ' $\mathrm{b}$ ' indicates values significantly different from $3 \mathrm{Sp} 1-\mathrm{p}(-20 /+26)$ luc vector $(P<0.01)$. 
-98 and $-20 \mathrm{bp}$ is highly involved in the promoter activity.

To further confirm the involvement of this binding site, a construct containing three Sp1-76 elements inserted upstream of the $\mathrm{p}(-20 /+26)$ luc vector was used to transfect HEK293 cells. Using this last construct, the basal promoter activity was increased by 10 -fold compared with the $\mathrm{p}(-20 /+26)$ luc vector alone in the same order of magnitude as the induction obtained using the $\mathrm{p}(-98 /+26)$ luc vector $(18$-fold) (Fig. 4C).

Using nuclear cell extracts prepared from either HEK293 or GT1-7 cell lines and a fragment of the $h M C 4-R$ gene promoter containing the Spl-binding site as probe, EMSA revealed that a major complex (C2) was formed (Fig. 5A). This DNA-protein complex was zinc-dependent (Fig. 5A), suggesting the binding of a zinc-finger protein. As shown in Fig. 5B, the complex formation was inhibited by a 200-fold molar excess of cold native oligonucleotide. In contrast, there was no competition using unlabelled oligonucleotides bearing either an unrelated sequence (CRE-binding site) or a mutated Spl-binding sequence. A second complex (C3), which migrated more rapidly than the complex C2, appeared to be specific as its formation was inhibited by an excess of unlabelled probe.

To identify the protein $(\mathrm{s})$ bound to both complexes, we used antibodies prepared against either $\mathrm{Sp} 1$ or Sp3. A supershifted complex (ss2) as well as a decreased intensity of the complex C2 was observed after preincubation of the nuclear proteins prepared from HEK293 cells in the presence of the Spl specific antiserum (Fig. 6A). This complex was not affected by the presence of Spl antibodies using GT1-7 cell nuclear extracts (Fig. 6A). In a previous report, Belsham \& Mellon (2000) did not detect Spl supershift using the $\mathrm{Sp} 1$ consensus oligonucleotide as a probe in the presence of GT1-7 nuclear extract. This result could not be explained by an absence of Spl expression in these cells as Sp1 was expressed in HEK293 cells but also (at a lower level) in GT1-7 cells, as demonstrated by Western blot analysis (Fig. 6B).

When a preincubation in the presence of Sp3 antibodies was performed using nuclear proteins prepared from either HEK293 or GT1-7 cells, a supershifted complex (ss3) was also observed in parallel with the disappearance of the complex C3 (Fig. 6A). We therefore concluded that the complex C2 contained the Sp1 protein in HEK293 cells and an Sp1-related protein in GT1-7 nuclear extract, but Sp3 was involved in the formation of the complex C3 in both cell types.

To further confirm the binding of Sp1 (HEK293 cells) or an Spl-related protein (GT1-7 cells) to the $h M C 4-R$ gene proximal promoter region, we used a 200-fold molar excess of unlabelled Spl consensus sequence to compete the Spl-MC4-R fragment used as labelled

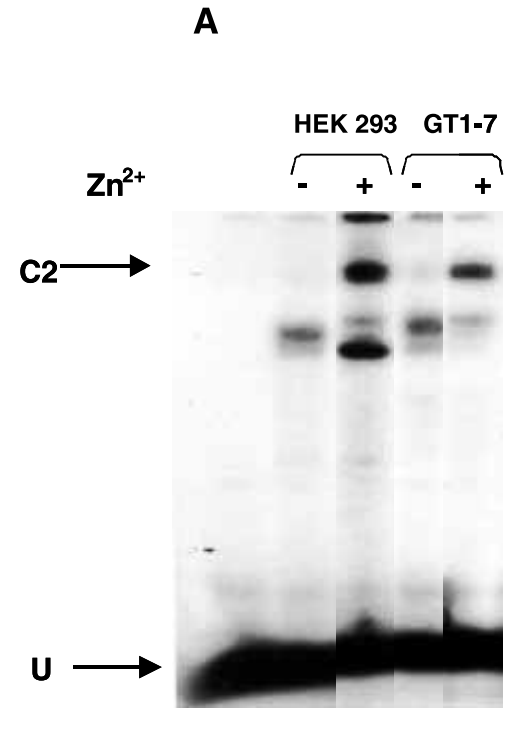

B $\quad$ HEK293 GT1-7
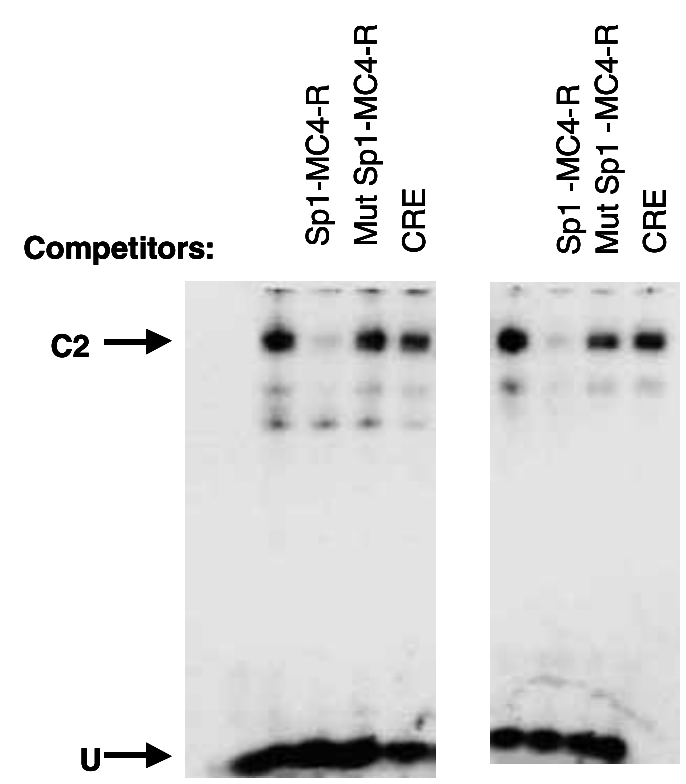

Figure 5 Analysis of the region located between -98 and -20 bp of the $h M C 4-R$ gene promoter by EMSA. (A). EMSA was performed using nuclear extracts from HEK293 and GT1-7 cells and the end-labelled Sp1-hMC4-R oligonucleotide as probe in the presence or not of $\mathrm{Zn}^{2+}$. The arrow indicates the position of the Sp1-hMC4-R (C2) complex. U=unbound probe. (B). The Sp1-hMC4-R oligonucleotide was 5'-end labelled and incubated with nuclear extracts obtained from HEK293 and GT1-7 cells, either alone or in the presence of a 200-fold molar excess of unlabelled double-stranded oligonucleotides (Sp1-MC4-R, mut Sp1-MC4-R, CRE).

probe. This $\mathrm{Spl}$ consensus oligonucleotide completely abolished the appearance of the specific complex C2 (Fig. 6C). Moreover, when the labelled oligonucleotide 
(A)

HEK 293 GT1-7

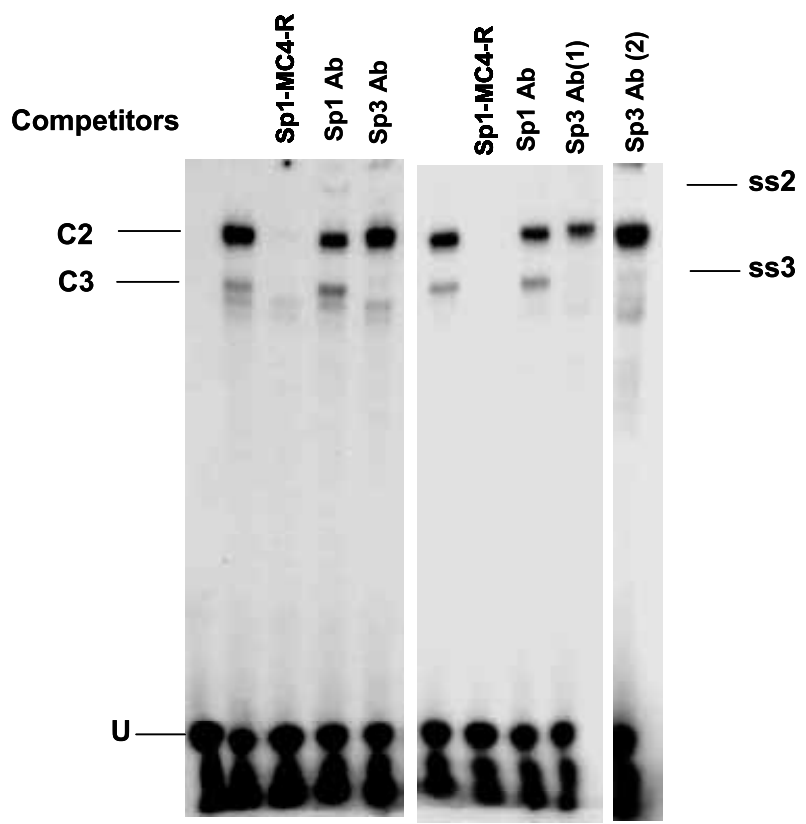

(B)

\section{GT1-7 HEK293}

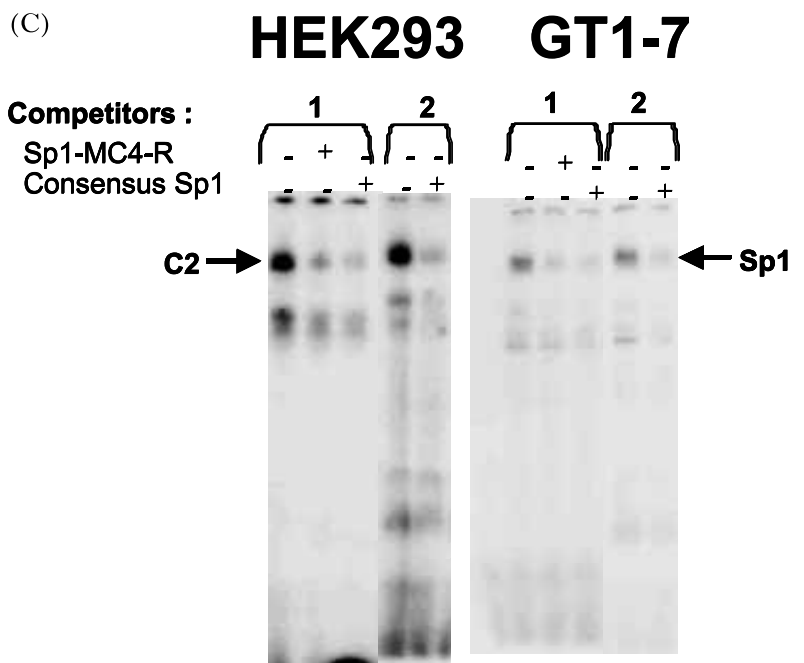

Figure 6 The Sp1 and Sp3 proteins bound the Sp1-76-binding site. (A) The Sp1-hMC4-R fragment was 5'-end labelled and incubated with nuclear extracts obtained from HEK293 and GT1-7 cells, in the presence of antibodies directed against Sp1 (Sp1 $\mathrm{Ab}$ ) or Sp3 (Sp3 Ab). Autoradiographs were exposed overnight except for the Sp3-Ab(2) band, which was exposed for 3 days. $\mathrm{U}=$ unbound probe. (B) Immunodetection of Sp1 in GT1-7 and HEK293 cell nuclear extracts. (C) Oligonucleotides containing either Sp1-hMC4-R (1) or consensus Sp1-binding site (2) were $5^{\prime}$-end labelled and incubated with nuclear extracts obtained from HEK293 and GT1-7 cells, either alone or in the presence of a 200-fold molar excess of unlabelled double-stranded oligonucleotides (Sp1-MC4-R and consensus Sp1).

containing the Spl consensus sequence was used as probe, one major complex was formed and migrated at the same position as the complex C2 (Fig. 6C) indicating that this complex contained the Spl transcription factor or related factor in HEK293 and GT1-7 cells respectively.

\section{The Sp1 and Sp3 proteins interact with the hMC4-R gene promoter in vivo}

The in vivo interaction between the Sp1-76-binding site and the Spl and Sp3 proteins was demonstrated by ChIP assay using HEK293 cells (Fig. 7A). PGR products obtained using the Sp1-76 primer pair and the negative control primers were 155 and 157 bp in size respectively. Input genomic DNA and Sp1 and Sp3 antibody ChIP DNA gave a strong PCR amplification using the Sp1-76 primer pair, but there was only a slight amplification using the negative control ChIP DNA (IgG) as a template (Fig. 7A). On the contrary, amplifications were equivalent for both $\mathrm{Spl}$ or $\mathrm{Sp} 3$ antibody $\mathrm{ChIP}$ and negative control ChIP (IgG) DNAs when the negative control primers were used. These data indicate that Sp1 and Sp3 bind in vivo (as well as in vitro) to the Sp1-76 site present on the $h M C 4-R$ gene promoter.

The major role of the Spl-binding site inside the $h M C 4-R$ gene promoter might be extended to the mouse gene as we found the same site in the published mouse promoter sequence at position $-87 \mathrm{bp}$ upstream of the transcription start site (Fig. 8), which permitted us to perform ChIP assays using Sp3 antibody and GT1-7 cells. The specific PCR amplified a sequence containing this Spl-87 site present in the mouse promoter. We demonstrated an in vivo interaction between the mMC4-R Sp1-87-binding site and the Sp3 protein in GT1-7 cells (Fig. 7B).

\section{Control of the basal activity of the hMC4-R gene promoter by Sp1 transcription factor}

The effects of Spl on basal transcriptional activity of the $h M C 4-R$ gene promoter were examined using Drosophila SL-2 cells (Fig. 9A). This cell line is devoid of endogenous Sp family members (Courey \& Tjian 1988). Cells were cotransfected with $p(-279 /+26)$ luc and different amounts of pPacSpl. Overexpression of 
(A)

Negative control

IgG $\mathrm{Sp} 1$

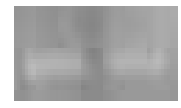

$\mathrm{IgG} \quad \mathrm{Sp} 3$

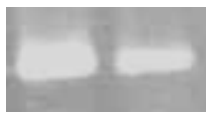

(B)

\section{Negative control}

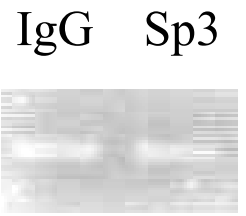

MC4R

IgG Sp1 Input

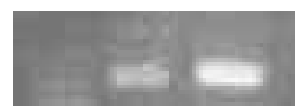

$\operatorname{IgG} \quad \mathrm{Sp} 3$

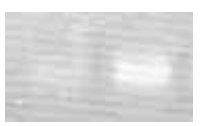

with the $\mathrm{p}(-279 /+26)$ luc construct, induced a strong decrease $(68 \%)$ of the luciferase activity (Fig. 9C). In contrast, it had no effect when the construct containing the mutated Spl was used. These results confirmed that, in HEK293 cells, Sp1 bound to the -76 binding site of the $h M C 4-R$ gene promoter to activate the transcription of this gene. No effect of mithramycin A was observed using GT1-7 cells (Fig. 9D), which confirms that, in this cell type, Sp1 did not bind to the Sp1-87-binding site present in the mouse promoter.

\section{Discussion}

The objective of this study was to better understand the transcriptional regulation of the $h M C 4-R$ gene in expressing tissues. The $h M C 4-R$ gene contained a unique exon as observed in the $m M C 4-R$ gene (Dumont et al. 2001). One major transcriptional start site, at position $-427 \mathrm{bp}$ from the ATG codon was identified. This is similar to the site at $-426 \mathrm{bp}$ found by Lubrano-Berthelier et al. (2003). Dumont et al. (2001) previously estimated a major transcription start site at 415 nucleotides upstream of the start of translation in $m M C 4-R$. The $h M C 4-R$ gene promoter did not contain a consensus TATA box, but a CAAT box was observed in an antisense orientation as described for the mMC4-R gene promoter (Dumont et al. 2001). The MC4-R belongs to a family of five melanocortin receptors. Promoter analyses have been mostly performed on two of the encoding genes, $h M C 1-R$ (Moro et al. 1999), $m M C 2-R$ and $h M C 2-R$ (Naville et al. 1994, 1997, Cammas et al. 1997, Shimizu et al. 1997) and these genes lack both TATA and CAAT boxes.

Promoter deletion studies allowed us to define two regions involved in the constitutive promoter activity of the $h M C 4-R$ gene. In the first region, mutation of the putative $\mathrm{Sp}-\mathrm{C} / \mathrm{EBP} \beta$ element only slightly decreased the promoter activity in HEK293 cells, suggesting that this element plays only a moderate role in the regulation of the basal $h M C 4-R$ gene expression. The protein which binds to this binding site is not related to Sp-like proteins or $\mathrm{C} / \mathrm{EBP} \beta$ and it remains to be identified.

We have focused our study on the second region which clearly drives the promoter activity. This region contained a putative Spl-binding site, the mutation of which dramatically reduced the basal promoter activity, demonstrating that a functional Spl-binding site was absolutely required for the activation of the $h M C 4-R$ gene promoter.

Insertion of three Sp1-76 elements in the $h M C 4-R$ gene promoter fragment $-20 /+26$, significantly increased the luciferase activity in HEK293 cells, demonstrating the essential role of this binding site in the expression of the hMC4-R gene. The fact that the 
$\operatorname{agactcccattgcattgggattggtcagaaggaagcagaggaggagccaccgtgaacatgtt}$
$\ldots \ldots \ldots \ldots \ldots \ldots \ldots \ldots \ldots \ldots \ldots \ldots$
tcagaaccactgaatacggattggtcagaaggaagcagaggaggagccattcagaacacccc

ttttttctctccacacatcataaatcagcagctggcgcctacagcccet +1 human

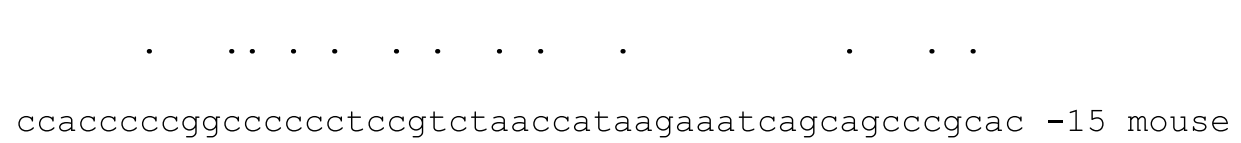

Figure 8 Sequence alignment of the $h M C 4-R$ and $m M C 4-R$ gene promoter. The Sp1-binding sites are in bold and the C/EBP $\beta$-binding site is underlined.

induction obtained with this construct was slightly lower than that obtained using $\mathrm{p}(-98 /+26)$ luc suggested that sequences present in the vicinity of the Spl-binding site were also necessary.

In HEK293 cells, the Spl transcription factor was able to bind the Sp1-76 site as demonstrated by EMSA using an antibody directed against Spl (complex C2). This result was confirmed using ChIP analyses. After cotransfection experiments with expression plasmid for Spl into SL-2 cells, which lack endogenous transcription factors of the Sp family and then cannot compensate for the absence of Spl by another factor of the same family, the promoter activity was significantly induced by expression of $\mathrm{Spl}$, which confirms the role of $\mathrm{Spl}$ in $h M C 4-R$ gene transcription. The importance of $\mathrm{Spl}$ binding was also confirmed by using mithramycin $\mathrm{A}$, a drug that specifically blocks Spl binding (Blume et al. 1991, Huang et al. 1991, Ryuto et al. 1996, Zhao et al. 2001). The physiological relevance of Spl binding transcriptional activity of the $M C 4-R$ gene was further confirmed by the strong decrease of the endogenous $M C 4-R$ gene expression in HEK293 cells after treatment with mithramycin. In addition to $\mathrm{Spl}$, the transcription factor Sp3 bound the same Spl-binding site as demonstrated by EMSA and ChIP analyses. The binding of both Sp1 and Sp3 to the same site has already been reported for other gene promoters, as in the case of the lutropin receptor (Chen et al. 2000).

Spl and Sp3 were able to bind the $h M C 4-R$ Spl-binding site both in vitro and in vivo in HEK293 cells, although this site did not correspond to the classic Sp1 consensus sequence. Indeed, it is known that Spl, one member of the $\mathrm{Sp} / \mathrm{XKLF}$ family of transcription factors, is able to recognize different sequences including GC boxes, GT boxes and CACG motifs (Gloss \& Bernard 1990, Li et al. 1991, Yu et al. 1991). Using GT1-7 cell nuclear extracts, we showed that the DNA-protein complex C2 did not contain $\mathrm{Sp} 1$, because there was neither competition nor supershift by $\mathrm{Spl}$ antibodies (Fig. 6A). The absence of supershift by $\mathrm{Spl}$ antibody using GT1-7 nuclear proteins has been reported (Belsham \& Mellon 2000) despite the evidence that Spl is present in these cells (Fig. 6B). Therefore, in GT1-7 cells, the absence of $\mathrm{Spl}$ in the complex C2 was not due to the absence of expression of this factor but may be related to the low expression levels of this factor. This could also be due to the absence of one particular co-factor in GT1-7 cells that may prevent a stable binding of $\mathrm{Spl}$ to the $\mathrm{Sp}$ site. Because several factors can compete for the same site, this could favour the binding of another related factor which may require another co-factor. An oligonucleotide containing a consensus Spl-binding site was able to competitively inhibit the formation of the $\mathrm{C} 2$ complex using GT1-7 cells in the present study. Therefore, an Spl-related protein could replace Spl in these cells.

$\mathrm{Spl}$ is an ubiquitous transcription factor present in all normal mammalian cells and plays an important role in basal expression of numerous genes lacking TATA boxes, such as those encoding structural proteins, metabolic enzymes, cell cycle regulators, transcription factors, growth factors, surface receptors and others (Braun \& Suske 1998, Courey \& Tjian 1988, Philipsen \& Suske 1999, Suske 1999). Spl is abundantly expressed in most cell types including those of the hypothalamus (Ren et al. 1998), and its level of expression changes during development and varies among different cell types (Lania et al. 1997, Suske 1999). Expression of Spl protein and mRNA appears to be highest in fetal cells (Saffer et al. 1991) and Spl - / - embryos display growth retardation and die early in gestation (Marin 


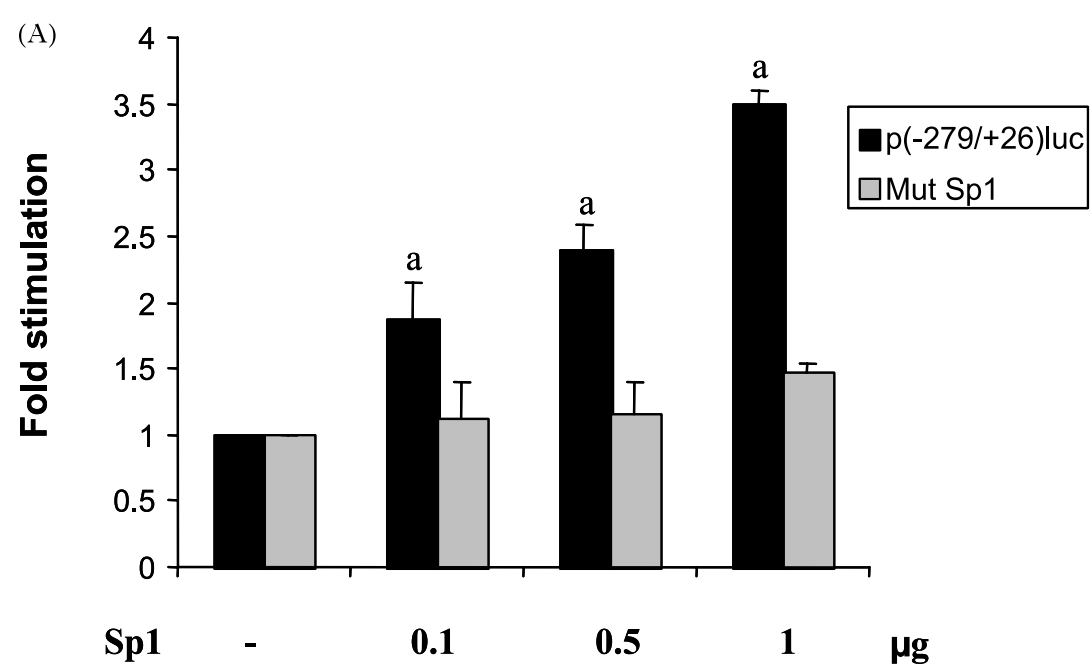

(B)
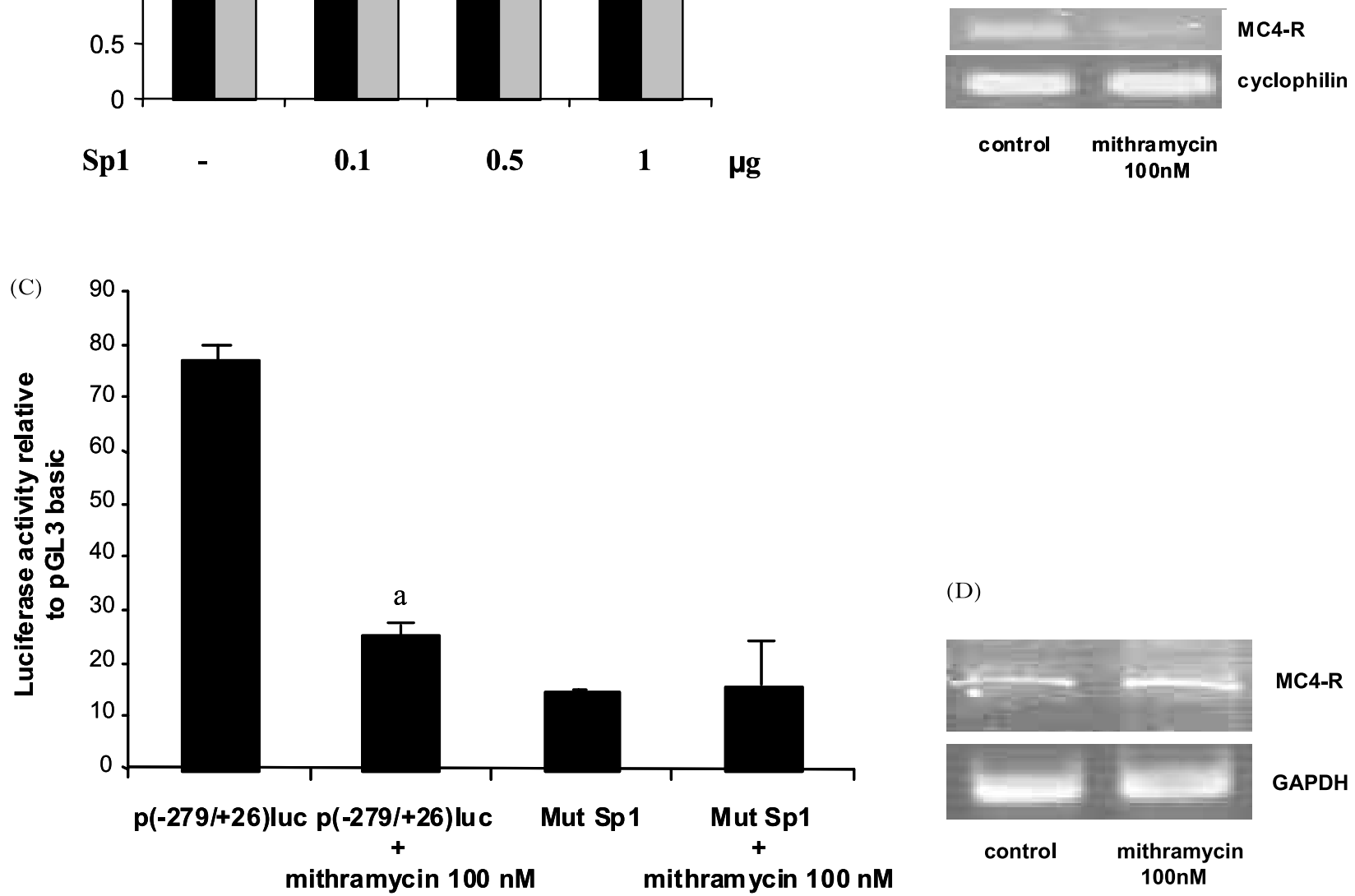

(D)

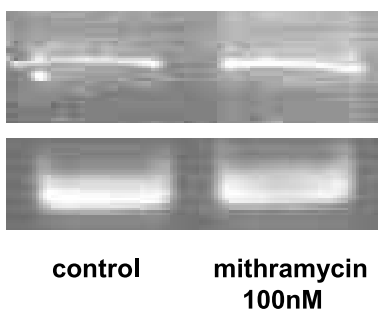

MC4-R

GAPDH

Figure 9 Role of the Sp1 protein in the transcriptional activity of the $h M C 4-R$ gene promoter. (A) Cotransfection experiments with an expression plasmid for Sp1, in SL-2 cells. The promoter-reporter gene constructs were the $p(-279 /+26)$ luc and the promoter mutated at the $-76 \mathrm{Sp1}$-binding site. The amounts of expression plasmid for Sp1 are indicated. Values represent the average of three independent transfections. 'a' indicates values significantly different from $\mathrm{p}(-279 /+26)$ luc in the absence of $\mathrm{Sp1}(P<0 \cdot 05)$. (B): Effect of mithramycin A on endogenous $h M C 4-R$ gene expression in HEK293 cells. RT-PCR on cell samples treated with or without $100 \mathrm{nM}$ mithramycin A for $24 \mathrm{~h}$. Cyclophilin was used as the reference gene. (C) Effect of mithramycin A on hMC4-R promoter activity. The promoter-reporter gene constructs used were the $p(-279 /+26)$ luc and the promoter mutated at the -76 Sp1-binding site. Cells were preincubated in the presence or absence of mithramycin A $100 \mathrm{nM} 24 \mathrm{~h}$ before transfection. Results are expressed as the fold induction over the respective pGL3 basic in the absence or presence of mithramycin A. This figure corresponds to a representative experiment and each data point is the mean \pm S.D. ' $a$ ' indicates values significantly different from corresponding control without mithramycin $\mathrm{A}(P<0 \cdot 05)$. (D) Effect of mithramycin A on endogenous mMC4-R gene expression in GT1-7 cells. RT-PCR on cell samples treated with or without $100 \mathrm{nM}$ mithramycin A for $24 \mathrm{~h}$. GAPDH was used as the reference gene.

et al. 1997). Similarly, the $M C 4-R$ gene is expressed during early ontogeny in the central and peripheral nervous systems.
In conclusion, we have shown for the first time that $\mathrm{Spl}$ (or a closely related facor) is absolutely required for the regulation of the activity of the $h M C 4-R$ gene; Spl 
could act through interplay with other specific factors, such as Sp3.

More study is needed in order to determine whether mutations of the Spl-binding site in the $h M C 4-R$ gene promoter might be linked to obesity.

\section{Acknowledgements}

We are grateful to S Drouva (Marseille, France) for providing the GT1-7 cell line and A M Clark for reviewing the English manuscript. A B was supported by grants from Nestlé and la Fondation pour la Recherche Médicale. The authors declare that there is no conflict of interest that would prejudice the impartiality of this scientific work.

\section{References}

Alvaro JD, Tatro JB, Quillan JM, Fogliano M, Eisenhard M, Lerner MR, Nestler EJ \& Duman RS 1996 Morphine down-regulates melanocortin-4 receptor expression in brain regions that mediate opiate addiction. Molecular Pharmacology 50 583-591.

Belsham DD \& Mellon PL 2000 Transcription factors Oct-1 and $\mathrm{C} / \mathrm{EBPbeta}$ (CCAAT/enhancer-binding protein-beta) are involved in the glutamate/nitric oxide/cyclic-guanosine $5^{\prime}$-monophosphatemediated repression of mediated repression of gonadotropinreleasing hormone gene expression. Molecular Endocrinology 14 212-228.

Blume SW, Snyder RC, Ray R, Thomas S, Koller CA \& Miller DM 1991 Mithramycin inhibits SP1 binding and selectively inhibits transcriptional activity of the dihydrofolate reductase gene in vitro and in vivo. Fournal of Clinical Investigation 88 1613-1621.

Braun H \& Suske G 1998 Combinatorial action of HNF3 and Sp family transcription factors in the activation of the rabbit uteroglobin/ CG10 promoter. Fournal of Biological Chemistry 273 9821-9828.

Cammas FM, Pullinger GD, Barker S \& Clark AJ 1997 The mouse adrenocorticotropin receptor gene: cloning and characterization of its promoter and evidence for a role for the orphan nuclear receptor steroidogenic factor 1. Molecular Endocrinology 11 867-876.

Chen S, Liu X \& Segalogg D 2000 A novel cyclic adenosine $3^{\prime}, 5^{\prime}$-monophosphate-responsive element involved in the transcriptional regulation of the lutropin receptor gene in granulosa cells. Molecular Endocrinology 14 1498-1508.

Chhajlani V \& Wikberg JE 1992 Molecular cloning and expression of the human melanocyte stimulating hormone receptor cDNA. FEBS Letters 309 417-420.

Chhajlani V, Muceniece R \& Wikberg JE 1993 Molecular cloning of a novel human melanocortin receptor. Biochemical and Biophysical Research Communications 195 866-873.

Courey AJ \& Tjian R 1988 Analysis of Spl in vivo reveals multiple transcriptional domains, including a novel glutamine-rich activation motif. Cell 55 887-898.

De Wied D \& Croiset G 1991 Stress modulation of learning and memory processes. Methods and Achievements in Experimental Pathology 15 167-199.

De Wied D \& Jolles J 1982 Neuropeptides derived from pro-opiocortin: behavioral, physiological, and neurochemical effects. Physiological Reviews 62 976-1059.

Dumont LM, Wu CS, Aschkenasi CJ, Elmquist JK, Lowell BB \& Mountjoy KG 2001 Mouse melanocortin-4 receptor gene 5 '-flanking region imparts cell specific expression in vitro. Molecular and Cellular Endocrinology 184 173-185.
Fan W, Boston BA, Kesterson RA, Hruby VJ \& Cone RD 1997 Role of melanocortinergic neurons in feeding and the agouti obesity syndrome. Nature 385 165-168.

Feng JD, Dao T \& Lipton JM 1987 Effects of preoptic microinjections of alpha-MSH on fever and normal temperature control in rabbits. Brain Research Bulletin 18 473-477.

Gantz I, Konda Y, Tashiro T, Shimoto Y, Miwa H, Munzert G, Watson SJ, DelValle J \& Yamada T 1993a Molecular cloning of a novel melanocortin receptor. Fournal of Biological Chemistry 268 8246-8250.

Gantz I, Miwa H, Konda Y, Shimoto Y, Tashiro T, Watson SJ, DelValle J \& Yamada T 1993b Molecular cloning, expression, and gene localization of a fourth melanocortin receptor. Fournal of Biological Chemistry 268 15174-15179.

Gee CE, Chen CL, Roberts JL, Thompson R \& Watson SJ 1983 Identification of proopiomelanocortin neurones in rat hypothalamus by in situ cDNA-mRNA hybridization. Nature 306 374-376.

Giraudo SQ Billington CJ \& Levine AS 1998 Feeding effects of hypothalamic injection of melanocortin-4 receptor ligands. Brain Research 809 302-306.

Gloss B \& Bernard HU 1990 The E6/E7 promoter of human papillomavirus type 16 is activated in the absence of $\mathrm{E} 2$ protein by a sequence-aberrant Sp1 distal element. Fournal of Virology 64 $5577-5584$.

Graham FL \& van der Eb AJ 1973 A new technique for the assay of infectivity of human adenovirus 5 DNA. Virology $\mathbf{5 2}$ 456-467.

Harrold JA, Widdowson PS \& Williams G 1999 Altered energy balance causes selective changes in melanocortin-4(MC4-R), but not melanocortin-3 (MC3-R), receptors in specific hypothalamic regions: further evidence that activation of MC4- $\mathrm{R}$ is a physiological inhibitor of feeding. Diabetes 48 267-271.

Huang TS, Lee SC \& Lin JK 1991 Suppression of c-Jun/AP-1 activation by an inhibitor of tumor promotion in mouse fibroblast cells. PNAS $\mathbf{8 8}$ 5292-5296.

Huszar D, Lynch CA, Fairchild-Huntress V, Dunmore JH, Fang Q, Berkemeier LR, Gu W, Kesterson RA, Boston BA, Cone RD et al. 1997 Targeted disruption of the melanocortin-4 receptor results in obesity in mice. Cell $\mathbf{8 8} 131-141$.

Jacobowitz DM \& O'Donohue TL 1978 alpha-Melanocyte stimulating hormone: immunohistochemical identification and mapping in neurons of rat brain. PNAS 75 6300-6304.

Joseph SA, Pilcher WH \& Bennett-Clarke C 1983 Immunocytochemical localization of ACTH perikarya in nucleus tractus solitarius: evidence for a second opiocortin neuronal system. Neuroscience Letters 38 221-225.

Lania L, Majello B \& De Luca P 1997 Transcriptional regulation by the $\mathrm{Sp}$ family proteins. International Fournal of Biochemistry and Cell Biology 29 1313-1323.

Li R, Knight JD, Jackson SP, Tjian R \& Botchan MR 1991 Direct interaction between Spl and the BPV enhancer E2 protein mediates synergistic activation of transcription. Cell $\mathbf{6 5}$ 493-505.

Li SJ, Varga K, Archer P, Hruby VJ, Sharma SD, Kesterson RA, Cone RD \& Kunos G 1996 Melanocortin antagonists define two distinct pathways of cardiovascular control by alpha- and gamma-melanocyte-stimulating hormones. Fournal of Neuroscience $\mathbf{1 6}$ $5182-5188$

Lubrano-Berthelier G, Cavazos M, Le Stunff C, Haas K, Shapiro A, Zhang S, Bougneres P \& Vaisse C 2003 The human MC4R promoter: characterization and role in obesity. Diabetes $\mathbf{5 2}$ 2996-3000.

Marin M, Karis A, Visser P, Grosveld F \& Philipsen S 1997 Transcription factor Spl is essential for early embryonic development but dispensable for cell growth and differentiation. Cell 89 619-628.

Marsh DJ, Hollopeter G, Huszar D, Laufer R, Yagaloff KA, Fisher SL, Burn P \& Palmiter RD 1999 Response of melanocortin-4 
receptor-deficient mice to anorectic and orexigenic peptides. Nature Genetics 21 119-122.

Moro O, Ideta R \& Ifuku O 1999 Characterization of the promoter region of the human melanocortin-1 receptor (MC1R) gene. Biochemical and Biophysical Research Communications 262 452-460.

Mountjoy KG, Robbins LS, Mortrud MT \& Cone RD 1992 The cloning of a family of genes that encode the melanocortin receptors. Science 257 1248-1251.

Naville D, Barjhoux L, Jaillard C, Lebrethon MC, Saez JM \& Begeot M 1994 Characterization of the transcription start site of the ACTH receptor gene: presence of an intronic sequence in the 5'-flanking region. Molecular and Cellular Endocrinology 106 131-135.

Naville D, Jaillard C, Barjhoux L, Durand P \& Begeot M 1997 Genomic structure and promoter characterization of the human ACTH receptor gene. Biochemical and Biophysical Research Communications 230 7-12.

Palkovits M, Mezey E \& Eskay RL 1987 Pro-opiomelanocortinderived peptides (ACTH/beta-endorphin/alpha-MSH) in brainstem baroreceptor areas of the rat. Brain Research 436323 338.

Philipsen S \& Suske G 1999 A tale of three fingers: the family of mammalian $\mathrm{Sp} / \mathrm{XKLF}$ transcription factors. Nucleic Acids Research 27 2991-3000.

Ren Y, Satoh T, Yamada M, Hashimoto K, Konaka S, Iwasaki T \& Mori M 1998 Stimulation of the preprothyrotropin-releasing hormone gene by epidermal growth factor. Endocrinology $\mathbf{1 3 9}$ 195-203.

Ryuto M, Ono M, Izumi H, Yoshida S, Weich HA, Kohno K \& Kuwano M 1996 Induction of vascular endothelial growth factor by tumor necrosis factor alpha in human glioma cells. Possible roles of SP-1. Fournal of Biological Chemistry 271 28220-28228.
Saffer JD, Jackson SP \& Annarella MB 1991 Developmental expression of $\mathrm{Spl}$ in the mouse. Molecular and Cellular Biology 11 2189-2199.

Schreiber E, Matthias P, Muller MM \& Schaffner W 1989 Rapid detection of octamer binding proteins with 'mini-extracts', prepared from a small number of cells. Nucleic Acids Research 17 6419.

Shimizu C, Kubo M, Saeki T, Matsumura T, Ishizuka T, Kijima H, Kakinuma M \& Koike T 1997 Genomic organization of the mouse adrenocorticotropin receptor. Gene $\mathbf{1 8 8} 17-21$.

Suske G 1999 The Sp-family of transcription factors. Gene $\mathbf{2 3 8}$ 291-300.

Vaisse C, Clement K, Guy-Grand B \& Froguel P 1998 A frameshift mutation in human MC4R is associated with a dominant form of obesity. Nature Genetics 20 113-114.

Yeo GS, Farooqi IS, Aminian S, Halsall DJ, Stanhope RG \& O'Rahilly S 1998 A frameshift mutation in MC4R associated with dominantly inherited human obesity. Nature Genetics $\mathbf{2 0}$ $111-112$.

Yu CY, Motamed K, Chen J, Bailey AD \& Shen CK 1991 The CACG box upstream of human embryonic epsilon globin gene binds $\mathrm{Spl}$ and is a functional promoter element in vitro and in vivo. Journal of Biological Chemistry 266 8907-8915.

Zhao X, Martin MM \& Elton TS 2001 The transcription factors $\mathrm{Spl}$ and Sp3 are required for human angiotensin II type 1 receptor gene expression in H295-R cells. Biochimica et Biophysica Acta 1522 195-206.

Received 7 December 2004

Accepted 14 December 2004 